\title{
ANALISIS FAKTOR KOMPETENSI DAN MOTIVASI KERJA \\ DALAM MEMBENTUK SIKAP KERJA PROFESIONAL
}

\author{
Danan Satriyo Wibowo \\ d.satriyowibowo@yahoo.co.id
}

Fakultas Psikologi Universitas Muhammadiyah Jember

\begin{abstract}
ABSTRAK
Keberadaan sumber daya manusia dalam organisasi memiliki posisi yang sangat vital. Keberhasilan organisasi sangat ditentukan oleh kualitas orang-orang yang bekerja di dalamnya. Seiring dengan persaingan yang semakin tajam karena perubahan teknologi yang cepat dan lingkungan yang begitu drastis pada setiap aspek kehidupan manusia maka setiap organisasi membutuhkan sumber daya manusia yang mempunyai kompentensi agar dapat memberikan pelayanan yang prima dan bernilai. Dengan kata lain organisasi tidak hanya mampu memberikan pelayanan yang memuaskan (customer satisfaction) tetapi juga berorientasi pada nilai (customer value).

Sumber daya manusia yang memiliki nilai tinggi adalah mereka yang berkompetensi dibidang kerjanya, memiliki skill dan keahlian yang menunjang dalam melaksanakan perkerjaannya. Disamping karyawan memiliki kompetensi, keberhasilan seorang karyawan juga di pengaruhi oleh motivasi dalam bekerja. Motivasi kerja menjadi peran penting dalam diri seorang karyawan, karena dengan memiliki motivasi kerja yang tinggi dan terukur seorang karyawan akan lebih mudah dalam mencapai tujuan dan memperoleh hasil kerja yang baik. Hal ini karena dengan memiliki motivasi, seorang karyawan akan merencanakan kinerjanya secara matang dan akan menunjukkan performa kinerja yang baik, selain itu dengan bekerja dengan motivasi dan berkompetensi seorang karyawan akan berupaya menunjukkan sikap kerja yang profesional.
\end{abstract}

Kata kunci: kompetensi, motivasi kerja, sikap kerja profesional

\section{A. PENDAhuluan}

Keberadaan sumber daya manusia dalam organisasi memiliki posisi yang sangat vital. Keberhasilan organisasi sangat ditentukan oleh kualitas orang-orang yang bekerja di dalamnya. Perubahan lingkungan yang begitu cepat menuntut kemampuan mereka dalam menangkap fenomena perubahan tersebut, menganalisa 
dampaknya terhadap organisasi dan menyiapkan langkah-langkah guna menghadapi kondisi tersebut. Seiring dengan persaingan yang semakin tajam karena perubahan teknologi yang cepat dan lingkungan yang begitu drastis pada setiap aspek kehidupan manusia maka setiap organisasi membutuhkan sumber daya manusia yang mempunyai kompentensi agar dapat memberikan pelayanan yang prima dan bernilai. Dengan kata lain organisasi tidak hanya mampu memberikan pelayanan yang memuaskan (customer satisfaction) tetapi juga berorientasi pada nilai (customer value).

Kinerja setiap kegiatan dan individu merupakan kunci pencapaian produktivitas. Karena kinerja adalah suatu hasil dimana orang-orang dan sumber daya lain yang ada dalam organisasi secara bersama-sama membawa hasil akhir yang didasarkan pada tingkat mutu dan standar yang telah ditetapkan. Konsekuensinya, organisasi memerlukan sumber daya manusia yang memiliki keahlian dan kemampuan yang unik sesuai dengan visi dan misi organisasi.

Sumber daya manusia yang memiliki nilai tinggi adalah mereka yang berkompetensi dibidang kerjanya, memiliki skill dan keahlian yang menunjang dalam melaksanakan perkerjaannya. Disamping karyawan memiliki kompetensi, keberhasilan seorang karyawan juga di pengaruhi oleh motivasi dalam bekerja. Motivasi kerja menjadi peran penting dalam diri seorang karyawan, karena dengan memiliki motivasi kerja yang tinggi dan terukur seorang karyawan akan lebih mudah dalam mencapai tujuan dan memperoleh hasil kerja yang baik. Hal ini karena dengan memiliki motivasi, seorang karyawan akan merencanakan kinerjanya secara matang dan akan menunjukkan performa kinerja yang baik, selain itu dengan bekerja dengan motivasi dan berkompetensi seorang karyawan akan berupaya menunjukkan sikap kerja yang profesional.

\section{Kompetensi}

Kompetensi didefinisikan (Spencer and Spencer,1993) sebagai an underlying characteristic's of an individual which is causally related to criterion-referenced 
effective and or superior performance in a job or situasion. Atau karakteristik yang mendasari seseorang dan berkaitan dengan efektifitas kinerja individu dalam pekerjaannnya. kompentensi seorang individu merupakan sesuatu yang melekat dalam dirinya yang dapat digunakan untuk memprediksi tingkat kinerjanya. Kemampuan dan keterampilan mendapat perhatian yang cukup besar dalam lingkaran manajemen masa kini. Penggunaan istilah kompetensi merupakan istilah yang digunakan untuk menjelaskan hal ini. Sesuatu yang dimaksud bisa menyangkut motif, konsep diri, sifat, pengetahuan maupun kemampuan atau keahlian.

Kompentensi individu yang berupa kemampuan dan pengetahuan bisa dikembangkan melalui pendidikan dan pelatihan. Spencer dan Spencer (1993) membagi kompetensi kedalam dua kategori, yaitu threshold competencies dan differentiating competencies. Spencer dan Spencer menyatakan threshold competencies sebagai karakteristik utama yang harus dimiliki oleh seseorang agar dapat melaksankan pekerjaannya, namun tidak untuk membedakan seseorang yang berkinerja tinggi dan rata-rata. Differentiating competencies adalah faktor-faktor yang membedakan individu yang berkinerja tinggi dan rendah.

Spencer dan Spencer (1993) menyatakan bahwa kompetensi individu merupakan karakter sikap dan perilaku kemampuan individual yang relatif bersifat stabil ketika menghadapi suatu situasi di tempat kerja yang terbentuk dari sinergi antara watak, konsep diri, motivasi internal, serta kapasitas pengetahuan kontekstual. Terdapat setidaknya lima karakteristik kompetensi yang akan membentuk sikap kerja dari seorang individu karyawan, yaitu:

1) Motif (motives), yaitu sesuatu yang dipikirkan atau diinginkan oleh seseorang secara konsisten dan adanya dorongan untuk mewujudkannya dalam bentuk tindakan-tindakan. Marshall (2003) juga mengatakan bahwa motif adalah pikiranpikiran dan preferensi-preferensi tidak sadar yang mendorong perilaku karena perilaku merupakan sumber kepuasan. Motif mendorong, mengarahkan, dan memilih perilaku menuju tindakan atau tujuan tertentu. 
2) Watak (traits), yaitu karakteristik mental dan konsistensi respon seseorang terhadap rangsangan, tekanan, situasi, atau informasi. Hal ini dipertegas oleh Marshall (2003) yang mengatakan bahwa watak adalah karakteristik yang mengakar pada diri seseorang dan mencerminkan kecenderungan yang dimilikinya.

3) Konsep diri (self concept), yaitu tata nilai luhur yang dijunjung tinggi oleh seseorang, yang mencerminkan tentang bayangan diri atau sikap diri terhadap masa depan yang dicita-citakan atau terhadap suatu fenomena yang terjadi di lingkungannya. Marshall (2003) juga mengungkapkan bahwa konsep diri adalah gambaran yang dimiliki seseorang mengenai dirinya sendiri dan hal mencerminkan identitas dirinya.

4) Pengetahuan (knowledge), yaitu informasi yang memiliki makna yang dimiliki seseorang dalam bidang kajian tertentu.

5) Keterampilan ( $s k i l l$ ), yaitu kemampuan untuk melakukan suatu pekerjaan fisik atau mental, keterampilan adalah aspek perilaku yang bisa dipelajari melalui latihan yang digunakan untuk memenuhi tuntutan pekerjaan.

Lima karakteristik tersebut memberikan gambaran tentang aspek-aspek yang saling terkait, sehingga membentuk sikap kerja seorang karyawan untuk bekerja secara profesional berdasarkan bidang kompetensinya. Melalui karakteristik kompetensi tersebut, perusahaan dapat memetakan kebutuhan pengembangan karyawan di kemudian hari sesuai dengan kondisi karyawan. Sebagaimana Spencer dan Spencer (1993) mengklasifikasikan dimensi dan komponen kompetensi menjadi tiga hal, yaitu:

a) Kompetensi intelektual

Kompetensi intelektual adalah karakter sikap dan perilaku atau kemauan dan kemampuan intelektual individu (dapat berupa pengetahuan, keterampilan, pemahaman profesional, pemahaman kontekstual, dan lain-lain) yang bersifat relatif stabil ketika menghadapi permasalahan di tempat kerja, yang dibentuk dari 
sinergi antara watak, konsep diri, motivasi internal, serta kapasitas pengetahuan kontekstual.

b) Kompetensi emosional

Kompetensi emosional adalah karakter sikap dan perilaku atau kemauan dan kemampuan untuk menguasai diri dan memahami lingkungan secara objektif dan moralis sehingga pola emosinya relatif stabil ketika menghadapi berbagai permasalahan di tempat kerja yang terbentuk melalui sinergi antara watak, konsep diri, motivasi internal serta kapasitas pengetahuan mental/emosional (Spencer \& Spencer, 1993).

c) Kompetensi Sosial

Kompetensi sosial adalah karakter sikap dan perilaku atau kemauan dan kemampuan untuk membangun simpul-simpul kerja sama dengan orang lain yang relatif bersifat stabil ketika menghadapi permasalahan di tempat kerja yang terbentuk melalui sinergi antara watak, konsep diri, motivasi internal serta kapsitas pengetahuan sosial.

\section{Motivasi Kerja}

Motivasi merupakan suatu kondisi yang mendorong orang lain untuk dapat melaksanakan tugas-tugas sesuai dengan fungsinya dalam suatu organisasi. Menurut Robbins (2003), motivasi adalah suatu proses yang meliputi usaha seseorang secara intens, terarah, dan teratur untuk mencapai suatu tujuan. Dengan demikian motivasi merupakan suatu tindakan untuk memengaruhi seseorang agar berperilaku secara teratur. Hal ini menunjukkan bawa di dalam suatu motivasi terdapat hal, yaitu: upaya, tujuan organisasi, dan kebutuhan dari seseorang dalam mencapai suatu tujuan dari kinerjanya.

Motivasi bersumber pada dalam diri seseorang (karyawan) yang berupa kesadaran mengenai pentingnya manfaat pekerjaan yang dilaksanakannya. Dalam perkembangannya terkait dengan motivasi kerja karyawan, motivasi dapat dipandang menjadi empat pendekatan (Bangun, 2012), diantaranya adalah: 
1) Pendekatan tradisional, yaitu model motivasi yang menitik beratkan pada pengawasan dan pengarahan.

2) Pendekatan hubungan manusia, yaitu memotivasi karyawan dengan memenuhi kebutuhan sosial dan menjadikan mereka merasa berguna.

3) Pendekatan sumber daya, yaitu memotivasi karyawan untuk meningkatkan kepuasan dan kinerjanya.

4) Pendekatan kontempoler, yaitu menekankan pada kebutuhan-kebutuhan manusia, menjelaskan berbagai kebutuhan manusia yang memengaruhi kegiatannya dalam organisasi.

Melalui empat pendekatan tersebut, perusahaan dapat melakukan motivasi sesuai dengan kondisi karyawan yang dihadapi, sehingga karyawan yang di motivasi tersebut dapat menunjukkan performa kerja yang prima dan sikap kerja profesional sesuai dengan kompetensi dan keahliannya.

\section{Sikap Kerja Profesional}

Sikap kerja profesional dapat dimaknai sebagai performa kerja yang prima dengan melibatkan kompetensi, keahlian, dan seluruh potensi yang dimiliki oleh seseorang dalam aturan yang telah disepakati bersama untuk mencapai tujuan dan hasil yang telah ditentukan. Sikap kerja profesional ini menunjukkan sejauh mana kualitas sumber daya manusia (karyawan) yang dimiliki oleh perusahaan dalam mengembangkan diri dan mengembangkan perusahaan melalui kinerja yang terukur.

Sikap kerja profesional terwujud dari rasa tanggungjawab dalam melaksanakan pekerjaan, hasil pekerjaan, ketepatan serta kerapian hasil kerja, dan komitmen dalam melaksankan pekerjaan. Hal ini harus terwujud dalm perilau kerja seorang karyawan yang dinyatakan berkompetensi dan bermotivasi, karena kompetensi dan motivasi secara linear akan mengarahkan seseorang untuk bersikap profesional dalam kinerjanya. 


\section{Kompetensi, Motivasi Kerja, dan Sikap Kerja Profesional}

Seorang karyawan yang dinyatakan memiliki kompetensi kerja yang baik akan berupaya menunjukkan kompetensinya melalui hasil kinerjanya, hasil kinerja yang dilakukan akan semakin menunjukkan performa yang baik apabila diikuti oleh motivasi kerja yang tinggi. Hal ini menunjukkan bahwa, seseorang yang berkompetensi berbanding lurus dengan motivasi kerja yang dimiliki dalam dirinya, ini dapat dilihat dari karakteristik yang membentuk sikap kerja seorang karyawan dimana dengan motivasi yang tinggi, maka pekerjaan yang dilakukan akan menghasilkan performa yang baik. Kompetensi dan motivasi kerja nantinya akan mengarahkan seorang karyawan bersikap profesional dalam kinerjanya. Hal ini nampak dari kesiapannya dalam melaksanakan pekerjaan yang menjadi tanggung jawabnya.

\section{DAFTAR PUSTAKA}

Bangun, W. (2012). Manajemen sumber daya manusia. Jakarta: Penerbit Erlangga.

Marshall, P. (2003). Mengapa beberapa orang lebih sukses dari yang kainnya?. Manusia dan kompetensi panduan praktis untuk keunggulan bersaing. Editor Boulter, Murray Dalziel, dan Jackie Hill. Alih Bahasa. Bern. Hidayat. Penerbit PT Bhuana Ilmu Populer.

Noe, R.A. (2002). Employee training and development. Second Edition. McGrawHill Irwin.

Robbins, S.P \& Judge, T.A. (2007). Organizational behavior. New Jersey: Pearson International Edition.

Spencer, L.M. \& Signe, M.S. (1993). Competence work: Model for superior performance. John Wiley and Sons, Inc. 